\title{
Development of University Lecturers in Vietnam: Current Situation and Solutions
}

\author{
Guandong Song \\ Institute of Education Economy and Management \\ Northeastern University \\ Shenyang, China 110819
}

\begin{abstract}
On the basis of studying theoretical issues on management of lecturers, analyzing current status of lecturers and managing lecturers of Vietnamese universities, thesis proposes the solutions of the development of lecturers in Vietnamese universities in the current context, including 7 groups of solutions: legal solution; solution of improving the rights and obligations of university lecturers; solution of attracting, creating the source of lecturers in universities; solution of recruiting lecturers in universities; solution on treatment policies for lecturers in universities; solution of training and fostering lecturers in universities; solution of the examination, comment and evaluation of lecturers in universities.
\end{abstract}

\section{Keywords - lecturers; university lecturers; Vietnam}

\section{INTRODUCTION}

After thirty years of innovation and ten years of implementing "Education development strategy for the period of 2006-2015", Vietnamese university education has developed significantly in terms of scale and diversification of types and form of training. First step is adjustment of the system structure, improvement of the program, training process and mobilization of many social resources. The quality of university education in some sectors, fields and institutions of university education has had positive changes, has met the requirements of social economic development of the country step by step. University-level and post-graduate lecturers who are mainly trained at domestic educational institutions have contributed significantly to the country's renewal and development.

However, the demands of national industrialization and modernization, people's learning needs and requirements of international integration in the new period haven't yet met. Staffs, lecturers and educational administrators are limited. Therefore, development of lecturer source is an urgent task that needs to be focused on settlement.

\author{
Van Huy Thang
Institute of Education Economy and Management \\ Van Huy Thang
Institute of Education Economy and Management \\ Northeastern University \\ Shenyang, China 110819
}

\section{THE CURRENT STATUS OF LECTURERS AND THE MANAGEMENT OF LECTURERS IN VIETNAMESE UNIVERSITIES AT PRESENT}

\section{A. The Current Status of University Lecturers of Vietnam}

As of the academic year 2015-2016, according to report of University educational department, total number of fulltime lecturers of all universities all over the country is 61,190 people. In terms of pure numbers, this number has increased by more than 5,000 people in comparison with academic year 2013-2014 school year. But in terms of quality, the quality of university lecturers is significantly reduced. The number of $\mathrm{PhD}$ level lecturers in the universities currently accounts of $13.86 \%$, decreases in comparison with rate of $14.33 \%$ in the academic year 20132014. At present, there are only 6,217 university and college lecturers with doctoral degrees in whole country. Whole country has 376 universities and colleges but the number of lecturers with the title of professor is only 320 people, the number of associate professors is less than 2,000 lecturers. Meanwhile, the number of students in the country is now 1.7 million students, so the average number of students per lecturer is 28 [1].

After more than 30 years of innovation, university lecturers have developed greatly in both quantity and quality. However, there are still many certain limitations that are making the results not meet the goals and objectives. Looking back on the results of the development of lecturers, especially lecturers in the university that is shown in the following aspects:

1) Advantages: The contributions of university education: It has provided millions of human resources with college, university degrees, thousands of labors with master's degrees, $\mathrm{PhD}$ degrees for the country. These are the key forces of the process of industrialization, modernization of the country, of the development of the country in the period of innovation and international integration. The system of university training facilities has covered the whole country (62/63 provinces having universities). State investment in university education has accelerated, and the financial mechanism for university education has begun to be renewed. Educational quality monitoring mechanism is 
implemented. International relations grow relatively rapidly both at the national level and at the school level.

The lecturers in the university have been more and more improved both quantity and professional capacity. Knowledge, professional qualifications and practical operational capacity have been gradually improved in all aspects, contributing positively to the success of national renewal in the past.

The political stuff, moral qualities of the lecturers have been more and more stable, loyal to the revolutionary, besides young lecturers are people having ambition, dream, enthusiasm.

Foreign language skill, computer skill and political theory have been constantly improved.

Policy perspectives: Development of the lecturers in the 30 innovation years has had important changes in perception, ideological view, shown in mechanisms, policies and laws from recruitment, training and management, gradually met the requirements of social economic development of the country.

2) Disadvantages: The number and structure of lecturers hasn't met the immediate and long-term requirements; The lack status between the generations of lecturers in each agency and unit is still widespread; lack of next core lecturers with high professional qualifications. According to statistics to 2015-2016 academic year, there are only 61,000 lectures/1.7 million students in Vietnam. Thus, the average number of students per lecture is 28 . In comparison with the ratio of student/lecturer in some schools and average of the world, we see that except for the top universities in the world such as Harvard University has student/professor of 3.5 and student/lecture of 23/2. Countries with advanced university education generally have student/lecture of around $15-20$. With average of 28 students per lecture, Vietnam's current university education sector lacks about 40,000 to 50,000 lectures [2].

The quality of the lectures in Vietnam's university is weak, isn't corresponding to the development requirements of the country, society and integration trend. A simple measure of the lecture quality of a university is the composition structure of the lectures, in particular the number of $\mathrm{PhD}$, or $\mathrm{PhD} /$ lecture. This ratio of Vietnamese universities is only $12.43 \%$, while the average universities in the West is about 70\% [3]. With this comparison, the quality of Vietnamese university lecturers is clearly low. On the other hand, scientific achievements of lectures are still small. For example, the number of articles published in international professional magazines is not much. Scientific research is the scientific basis of knowledge and qualifications of lecturers, but it hasn't become the real needs of lectures. Themes and contents of scientific research are still heavy in form, don't link the requirements of reality [4].

State and social investment in education is more but it still spreads and lacks focus, although Vietnam is country which has the highest education expenditure in the world. Over the past 16 years $(2000$ - 2016), Vietnam government has gradually invested education and training from more than $13 \%$ to $20 \%$ of total state budget expenditure [5]. But infrastructure for education is still lack and backward, especially investment in equipment, construction and investment of practice facilities, experiment facilities for students is very limited, so it is very difficult for graduates to perform immediately trained professional jobs because they lack practical skills.

The sense of responsibility, sense of discipline of lecturers is still weak, the style of work is slow in innovation; the spirit of service, enthusiasm isn't high.

The education management mechanism is still limited. The state management of university education is still inadequate, the management and use mechanism, policy regime for university lecturers is unreasonable, not creating motivation for lectures to encourage and heighten the responsibility, strive to improve moral quality, work capacity.

\section{B. Status of Management of Vietnamese University Lectures}

It is forecasted that Vietnam's population will reach 100 million people by 2020 with about 23.5 million pupils and 4.5 million students. The natural increase in the scale of pupils and students every year; the decrease of pupil, student/class and the decrease of student/lecture require that scale of lectures must increase average of $5 \%$ per year, needing to have 1.25 million teachers by 2020 ; in which the number of lecturers must increase 4 times in comparison with the number of lectures at present with at least $25 \%$ of doctorate degrees (only pedagogical universities require $100 \%$ of lecturers with doctoral degrees) [6]. In recent years, the management of lecturers in the university has achieved certain successes, initially has brought certain effects for the development of university education, in particular:

1) From the perspective of state management: In the past time, the Party and State of Vietnam have issued quite adequate system of legal documents in the field of education and training. Legal documents have initially met and created the legal basis for promoting state management activity in university education effectively and have created the foundation for the development of university education.

The direction of the Ministry of Education and Training, the management of the affiliated units have had significant innovations. The Ministry has implemented well principle of concentration, democracy, created unity, unanimity, promoted the collective intellectual strength.

2) From the perspective of universities: Serious and full organization and implementation is in accordance with the legal normative documents of the state, strictly adhered to and follow direction of the higher state agencies in promoting the management of lectures.

Concentrate, ensure and raise the quality of training; actively promote scientific research activities in school. The results of research projects towards scientific and technological products which have high influence and scientific value. Universities have stepped improvement the professionalism and efficiency of management, 
administration and finance in the school, have built a humane technological research and training environment. At the same time, the domestic and foreign cooperation of schools institutes - businesses is strengthened.

However, management of lectures in universities is still limited, not comparable; so contribution for the development of education, industrialization and modernization and international economic integration is required. Specifically:

- The performance of the tasks as well as the quality and the teaching result is limited.

- The responsibility of the work, the working style of the lectures is still slow in innovation.

- Professional ethics, communication culture when performing duties, attitude of a part of lecturers don't meet requirement. A part of lectures is deteriorated on professional ethics, low responsibility sense.

- The planning and planning of the development of lectures aren't paid much attention so the arrangement and use of staffs follow situation and are passive, status of lack among generations of lecturers in each unit is going to happen in the future.

- Form and content of recruitment exams, examinations to raise scale for lecturers, method of assessing lecturers, regulations on lectures' rights and obligations ... as staffs and civil servants in state agencies aren't appropriate for the nature and characteristics of the lectures and this will lead to the "administrative" status of the organization and operation of the university.

From the above current situation, it is necessary to have solutions to improve the development of university lecturers in terms of quantity, quality, virtuous character and political stuff as well as adjustment legal mechanism.

\section{SOlutions TO BUILD TEAMS OF LECTURES IN THE UNIVERSITY OF VIETNAM AT PRESENT}

\section{A. Legal Solutions}

To ensure the success of revitalizing the education, contribute to intensify the industrialization, modernization and international integration more and more deeply, the construction and development of team of staffs and civil servants in universities should be implemented on a solid legal basis, which is legal document with high legal value:

1) "Legislate" the views and policies of the Party on building and developing the team of staffs and civil servants in universities, teachers and education administrators. Detail:

- Honoring teachers and teaching profession, raising the social position of teachers.

- Training team of teachers and education administrators, building pedagogic schools in order to ensure the adequate number of teachers at all educational levels, training levels and special subjects in the society.

- Improving the quality, capacity; standardizing team of teachers and educational administrators.

- Caring the material and spiritual life of teachers and educational administrators.

- Managing and using team of teachers and educational administrators.

2) "Legalizing" some of the regulations being adjusted by legal documents: About adjustment subject: Basic concepts should be defined: "schoolmaster", "teacher", "lecture"; "vocational teacher", "educational administrator" ... When there are uniform regulations, we will correctly determine the adjusted subjects in the process of implementing the relevant regimes and policies.

Occupational titles represent the level and professional competence of the staffs in each occupational field, so suitable identification mechanism should be established to ensure common status for those who are operating in this sector (including in public and private units).

Unlike staffs, civil servants, for officials it may not be necessary to classify them at the central authority or local authority, mainly we should classify their professional qualifications and quality of service.

Policy regimes for schoolmasters and educational administrators should be legalized to ensure legal validity and high implementation validity, ensure fair adjustment for all schoolmasters and educational administrators in public and non-public schools; ...

\section{B. Solution to Perfect the Rights and Obligations of University Lecturers}

It is necessary to give autonomy and self-responsibility of public service delivery agency; improve the provisions on the rights and obligations of the public officials towards the opening and connection with the non-public sector; extend the right of international cooperation and experience exchange in professional activities.

Set up system of rights and obligations of officials as the people who are given the right to serve, provide essential products and needs to the citizen.

It is necessary to stipulate the rights of officials in the direction of opening more than staffs and civil servants, create conditions for officials to develop their talents, creativity and ability of contribution in the current market mechanism condition. It is the right to contribute capital, participate in the establishment (but not directly participate in operating) types of enterprises and private public service delivery organizations; the right of work besides prescribed time; the right of signing contract with other agencies and organizations without being prohibited by law.

It should be built in the direction of promoting the role and responsibility of the head in public service delivery units in recruitment, use and management. Increase the mechanism of effective inspection and monitoring of the implementation to ensure democracy and objectivity and at 
the same time show the publicity and transparency of the decision-making process.

Rights and obligations, ethics, communication culture, things not to do of the officials in general don't differ much from regulations for staffs and civil servants.

\section{Solutions to Attract, Create Sources of Lecturers in University}

It is necessary to combine the creation of university lectures and the attraction of high-level lectures in the university:

Pay attention to the rules of the market economy, ensure competitiveness to improve the quality of service to people in the public service delivery fields.

Supplement and attract the elite citizens in society into the team of officials through measures of attracting and creating official human resources. Focus on fostering and training to raise the capacity, qualification and skill for team of lecturers.

\section{Solutions for Recruiting Lecturers in University}

Renovate method of managing officials from the payroll norms to determination of the number of employment positions in each public service delivery unit. Establishment of employment positions in public service delivery units with specific number instead of assignment and allocation of current payroll norms. Work contract must become a legal regulation on officials, show that one of the most important principles is equality and freedom of the will between the parties in the contract and the performance of the contract.

Recruitment must be objective, fair and scientific to the positions of employment recruitment; diversify the recruitment of lectures in the university according to open direction on the basis of work contract, contract of employment, determine the adjustment law, jurisdiction agency and dispute settlement mechanisms for this contract.

Continue to regulate the appointment, dismissal and resignation of leaders and managers on the basis of the views and policies of Party and State.

\section{E. Solutions for the Policy of Lecturer Treatment in the University}

Develop treatment policies to attract talents to work at universities on the basis of:

Construction and implementation of policies and regimes in recruitment; the working environment and conditions of ensuring the quality and effectiveness of the work of lecturers and educational administrators (especially for professors, associate professors, experts and advanced lecturers/ $\mathrm{PhD}$...); regime of salary, salary scale and salary table of the lectures, ...

In addition, lecturers are guaranteed the right to study, scientific research, participate in economic and social activities; enjoy preferential policies on house, means of transport, regime for social insurance and health insurance according to the provisions of law and other treatment regimes. At the same time, the regulations on commendation, handle of violations, complaints and settlement of complaints related to team of schoolmaster and education administrators should be ensured fairness and transparency

\section{F. Solutions for Training and Fostering Lecturers in the University}

Training and fostering of lecturers in the university is the process of organizing learning opportunities for lecturers to equip, update, improve knowledge, skills and working attitudes so that they can perform assigned jobs better, more effectively, meet the requirements of the learner, namely:

- Change from training according to "supply" (training what training institutions have, lecturers have) to training according to "demand" (training according to customer demand).

- Strengthen system of training and fostering facilities. Training facilities shall shift to service provision mode, build supply-demand relation between training facilities and management unit, use staffs and officials, create open and competitive mechanisms in providing training services.

- Unify State management on officials and training.

- Socialize the training officials.

- For leaders of universities, there should be a separate channel for training.

- Develop enough team of lecturers with management experience, practical experience and professional pedagogical skill.

\section{G. Solutions for the Examination, Comment and Evaluation of Lecturers in the University}

It is important to distinguish two types of evaluating officers as follows:

Firstly, evaluate the performance of the officials in a certain time. This assessment only focuses on assessment based on performance criteria such as implementation results, execution time, effectiveness cost, coordination ability in performance, diligent attitudes. Leader evaluates annually the implementation results of the officials.

Secondly, the assessment of the officials according to requirements of rotation, promotion, transfer ... This evaluation besides evaluation of performance results, also focuses on other evaluation criteria such as: professional ethics, service spirit ...

Renovate the assessment of officials in association with the results, time and progress of work completion in order to distinguish good working persons and not good working persons. As civil servants, if officials don't complete tasks for 2 consecutive years, they will be terminated working contract and apply regime of quitting job. 


\section{CONCLUSION}

Improving the quality of education and training and promoting the training according to social needs is one of the important contents in the current strategy of education and training development in Vietnam. Along with other factors, the university lectures have great role to play in achieving the goal and promoting the role of university education. Educational administrators should pay attention to the investment, construction and development of university lecturers with comprehensive goals in terms of quantity, quality and professional ethics, on the basis of determining specific tasks and practical solutions in line with practical conditions of Vietnam to meet demand for advanced human resource training in the international integration period.

\section{REFERENCES}

[1] Conference on summarizing the academic year and implementing tasks of the new academic year of universities and colleges held by the Ministry of Education and Training, Hanoi, 2016.

[2] Nguyen Thi Thu Huong, Development of lecturers in the university Current situation and solutions, Science magazine - Hanoi National University, 2012.

[3] Duong Thi Thanh Xuan, Improvement of the capacity of university lectures to meet the requirement of high quality human resources training, Journal of Political Theory No. 11-2016.

[4] Le Thi Phuong Nam, Hoang Van Loi, Current situation and solutions to improve the quality of university lecturers, Legislative Studies Institute, 2016.

[5] Vietnam Institute of Science and Education (2015), Yearbook of the Basic and Comprehensive Education Innovation Conference, Hanoi, November -2015

[6] Nguyen Hai Thap, Current situation of schoolmaster, educational administrators, and contents which need to be studied when building Law on Officials,, Department of schoolmaster and educational administrators- Ministry of Education and Training, Hanoi, 2014. 